\title{
What's New?
}

\author{
Marvin L. Birnbaum, MD, PhD
}

\author{
It is for man to tame chaos \\ On every side, whilst be lives, \\ to scatter the seeds of science and song, \\ That climate, corn, animals, men may be milder, \\ And the germs of love and benefit may be multiplied. \\ Ralph Waldo Emerson \\ Representative Men: Uses of Great Men
}

This issue of Prehospital and Disaster Medicine (PDM) marks the beginning of its 18th volume. This journal first was published in 1985 as the Journal of the World Association of Emergency and Disaster Medicine (JWADEM) with Peter Safar (University of Pittsburgh) as the Editor-in-Chief. R. Adam Cowley (Maryland Institute for Emergency Medical Services Systems) assumed the position of Editor in 1986. Then, for a brief period, The JWAEDM was not published. I assumed the editorship in 1988 when the resources of the World Association for Disaster and Emergency Medicine (WADEM) and the National Association of Emergency Medical Services Physicians (NAEMSP) were combined to create the present journal. This rebirth now included the burgeoning field of prehospital emergency medical services as well as disaster and emergency medicine.

This issue marks the progression of the journal into two areas: (1) the return of Editorial Comments following selected articles and a point-counterpoint section that discusses controversial aspects in this field of scientific endeavor; and (2) a regular Section dealing with International Health Law and Ethics discussions as they apply to Disaster and Emergency Medicine.

The first of these additions will be stewarded by Sam Stratton, MD, MPH from the University of California, Irvine and the University of California Los Angeles Center for Public Health and Disaster. Sam is a distinguished scientist and an excellent editor. He has served on the Editorial Board of PDM since 1993, and has contributed much to its gradual rise in quality. He has a broad knowledge of the entire field of acute care medicine from system entry through critical care and in disaster medicine and terrorism. He has an international reputation as a teacher and lecturer in a wide range of topics. His breadth of knowledge and experience make him an ideal editor to captain this difficult assignment. You will obtain a perspective as to his abilities by perusing his introductory editorial (page 2.) The objective of this Section is to further the science. It is not intended to be critical of the work commented on, only to push the science further along. Editorial Comments will be sought from those of you considered to be expert in the areas discussed in the articles being reviewed. If you know of issues that you believe will be appropriate for discussion in PDM, please contact Sam at: strattos@uci.edu

The new section on International Health Law and Ethics will be guided by Michael Hoffman, JD. Mike is an recognized practitioner of International Law and is an educator in this field who has taught international and crosscultural students in Europe, North America, the Middle East, and the Asia-Pacific region. He specializes in the law of armed conflict, humanitarian assistance, public health and safety, terrorism, peace operations, disaster response, national security, and refugee law. He is an adjunct associate professor for the Johns Hopkins University and the Matsunaga Institute for Peace of the University of Hawaii. His objectives for this section are to enhance our knowledge in this important field, to raise important issues relative to international law and the ethics associated with the practice of international health and emergency responses, and to examine the issues associated the relationships between international law, national legislation, and the ethics of such legislation and practices (page 4.) Those interested in participating in this section or who have issues that you believe should be discussed in this section should contact Mike at: michhof@comcast.net

The next two issues of PDM will be devoted to the medical aspects of terrorism worldwide. Under the remarkable efforts of Jeffrey Arnold, MD, the quantity of material collected far exceeds my ability to publish it all in one issue of PDM. The content of the material is exceptional and deals with the realities and visions of terrorism now and in the future. Combined, these two issues will define the state-ofthe-science and art of the medical aspects of terrorism.

Special thanks are in order to each of you, authors, readers, and advertisers, for helping get PDM to where it is. It is because of your commitment to building the SCIENCE of prehospital, emergency, disaster, and humanitarian medicine that this publication has become a most important element in this SCIENCE.

So our lives in acts exemplary, not only win Ourselves good names, but doth to others give Master for virtuous deeds, by which we live. Chapman: Bussy D'ambois. Act I, Scene 1 